\title{
Metastatic Axillary Lymph Node from Occult Breast Carcinoma: A Case Report
}

\author{
Gizli Meme Karsinomunda Metastatik Aksiller Lenf Nodu Bir Olgu Sunumu
}

\author{
Nor Faezan Abdul Rashid, Yahya Mohd Aripin
}

Department of Surgery, Faculty of Medicine, University Technology MARA, Sungai Buloh, Malaysia

\section{ABSTRACT}

Metastatic axillary lymph node from occult breast carcinoma poses a difficult and challenging management. It is a rare entity accounting only $0.3-1 \%$ cases of all breast cancer. It involves a multidisciplinary discussion and collaboration. Traditionally the treatment consists of mastectomy with axillary lymph node dissection however the practice patterns have steadily changed over the last two to three decades with an emphasized-on breast conservation therapy (BCT). Here we present a 58-year-old lady presented with enlarging right axilla swelling for one month without any breast lump or nipple discharge. Examination revealed 2 mobile right axilla lymph nodes with no palpable breast lump or demonstrable nipple discharge. Routine imaging including mammogram and ultrasound of the breast did not reveal any lesion except suspicious lymph nodes at the right axilla. Cytology of the lymph node showed suspicious of metastatic lesion. Magnetic resonance imaging of the breast also did not reveal any breast lesion. Positron emission tomography and computed tomography (PET CT) was done but did not show uptake to suggest primary lesion except uptake at the right axillary node and right internal mammary node. Excision biopsy of the right axillary node was proven to be metastatic carcinoma in keeping with breast as primary with negative for estrogen and progesterone receptor but c-erB2 positive. Mastectomy with axillary lymph node dissection was done and histopathology report was found to have $2 \times 1$ $\mathrm{mm}$, grade 2 tumor in the breast. Patient underwent adjuvant chemotherapy and radiotherapy and currently on trastuzumab and is doing well with no signs of loco regional recurrence or distant metastasis.

Key Words: Occult breast cancer, lymph node dissection, mastectomy, breast conservation therapy (BCT)

Received: 08.19 .2018
Accepted: 01.09.2019

\section{ÖZET}

Okult meme karsinomundan metastatik aksiller lenf nodu zor ve zorlu bir tedavi sunar. Tüm meme kanseri vakalarının sadece \% 0.3-1'ini oluşturan nadir bir varlıktır. Disiplinlerarası bir tartışma ve işbirliğini içerir. Geleneksel olarak, tedavi aksiller lenf nodu diseksiyonu ile birlikte mastektomiden ibarettir, ancak uygulama meme koruma tedavisi ile son iki ila üç yılda giderek değişmiştir. Burada, 58 yaşında bir kadına, herhangi bir meme kitlesi veya meme başı akıntısı olmadan bir ay boyunca genişleyen sağ aksilla şişmesi ile başvurdu. Muayenede, palpe edilebilen meme kitlesi veya meme başı akıntısı olmayan 2 mobil sağ aksilla lenf nodu tespit edildi. Mamografi ve memenin ultrasonu da dahil olmak üzere yapılan rutin görüntüleme sağ aksilladaki şüpheli lenf bezleri dışında herhangi bir lezyon göstermedi. Lenf bezinin sitolojisi metastatik lezyon şüphesi gösterdi. Memenin manyetik rezonans görüntülemesi de meme lezyonu göstermedi. Pozitron emisyon tomografisi ve bilgisayarlı tomografi (PET CT) yapıldı, ancak sağ aksiller nod ve sağ internal meme nodunda tutulma olmadan primer lezyon önerdiği gözlendi. Sağ aksiller nodun eksizyon biyopsisinin östrojen ve progesteron reseptörü için negatif, ancak c-erB2 pozitif olan primer metastatik meme karsinom olduğu kanıtlandı. Aksiller lenf nodu diseksiyonu ile mastektomi yapıldı ve histopatoloj raporunda memede $2 \times 1 \mathrm{~mm}$, grade 2 tümör tespit edildi. Hastaya adjuvan kemoterapi ve radyoterapi uygulandı ve şu anda trastuzumab uygulanmaktadır ve hasta lokal bölgesel nüks ya da uzak metastaz belirtileri olmadan iyi bir durumdadır.

Anahtar Sözcükler: Okult meme kanseri, lenf nodu diseksiyonu, mastektomi, meme koruyucu tedavi

Geliş Tarihi: 19.08.2018

Kabul Tarihi: 09.01.2019

\section{INTRODUCTION}

Metastatic axillary lymph node from an occult breast cancer is a rare occasion. Some reported axillary lymphadenopathy from occult breast carcinoma as $0.3-1 \%$ of all breast cancer (1). Occult breast cancer defined as cancer that has metastasized to the axilla in the absence of mammographic or physical findings of disease in the breast (2). Traditionally occult breast cancer was treated with mastectomy with axillary lymph node dissection, but the practice has changed now over the last two to three decades. Majority of the studies highlighted on the importance of removing the axillary nodes followed by radiotherapy to the breast also known as breast conservation therapy (BCT). Occult breast cancer poses a challenging management and not to mentioned, the stress on the patient for the unknown cancer origin. It may involve series of imaging modalities as well as a good collaboration with multidisciplinary teams including surgeon, radiologist, pathologist and oncologist. Here we report a rare case of occult breast cancer presenting as axillary lymphadenopathy without breast lesion.

\begin{abstract}
CASE REPORT
A 58-year-old lady with no underlying comorbidities presented to us with one-month history of painless enlarging right axilla swelling. Other than that, she did not have breast lump or nipple discharge. She has a strong family history of breast cancer as her sister was diagnosed at early 50s and her maternal cousin in her 30s. Examination revealed 2 mobile right axilla lymph nodes with no palpable breast lump or demonstrable nipple discharge. Otherwise, there was no other lymphadenopathy felt at the left axilla and both supraclavicular fossae. Mammogram and ultrasound of the breast did not reveal any suspicious lesion. Fine needle and cytology of the right axilla nodes showed suspicious metastatic lesion. Magnetic resonance imaging of the breast failed to yield any positive lesion. We proceeded with positron emission tomography and computed tomography (CT) (Figure 1 and 2) where they were presence of right axilla and right internal mammary nodal metastasis around $2.0 \times 1.2 \times 1.8 \mathrm{~cm}$. No uptake seen on both breasts.
\end{abstract}


Excision biopsy of right axilla node was done, and the histopathology revealed a metastatic carcinoma, in keeping with primary breast carcinoma with estrogen receptor (ER) and progesterone receptor (PR) negative, c-erB2 positive (CK 7 positive, CK 20 negative). After discussion with the patient, we proceeded with mastectomy and axillary dissection in view of occult breast carcinoma. Surprisingly, the histopathology report revealed a small focus of infiltrating ductal carcinoma, $2 \times 1 \mathrm{~mm}$, grade 2 with no lymphovascular invasion. The margin was clear, ER and PR were negative and c-erB2 was positive. Four out of seventeen lymph nodes were involved. CT staging was done after the surgery and showed no distant metastasis. She was well post operatively and currently completed six cycles of chemotherapy and radiotherapy to the chest wall. Surveillance so far showed no evidence of locoregional recurrence and she is now currently on trastuzumab treatment.

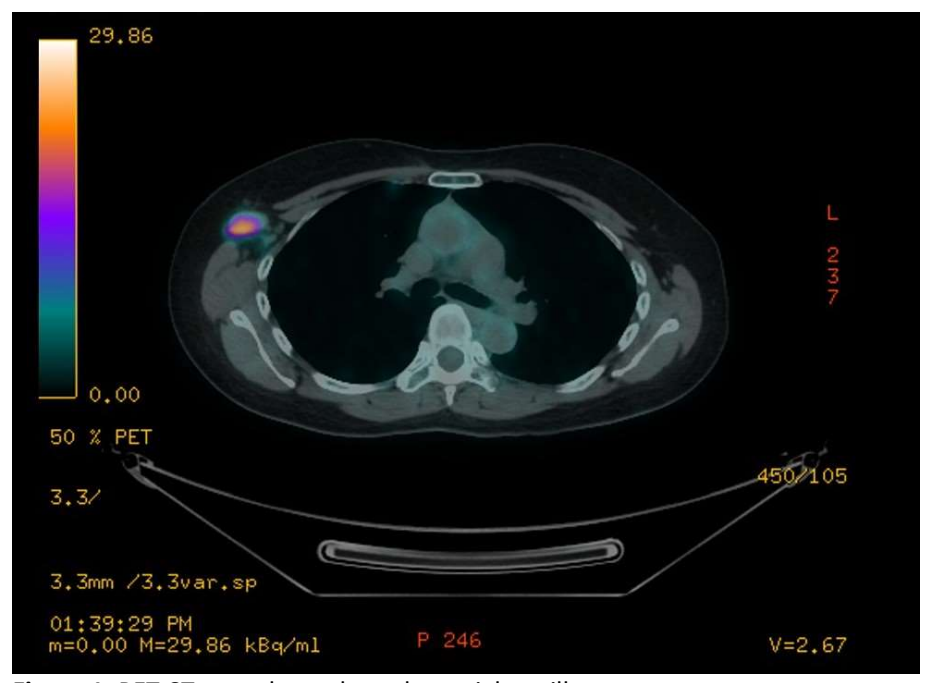

Figure 1: PET CT scan showed uptake at right axilla

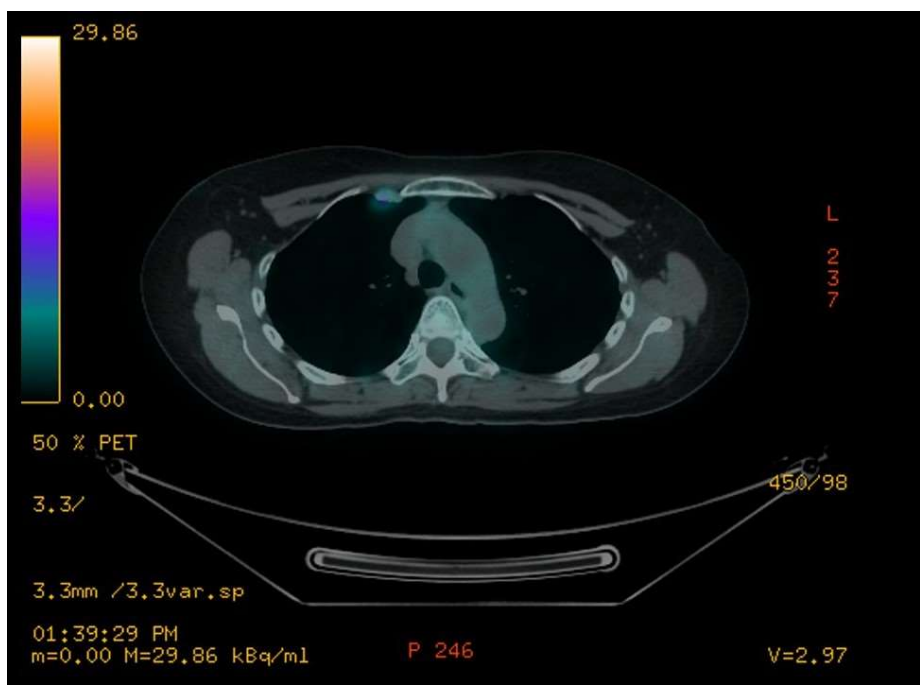

Figure 2: PET CT scan showed uptake at right internal mammary node

\section{DISCUSSION}

Halsted first described breast cancer presenting as axillary adenopathy with clinically occult breast tumour in 1907 (1). It is very rare and occurs in less than $1 \%$ of all breast cancers (2). Occult breast cancer is defined as cancer that has metastasized to the axilla in the absence of mammographic or physical findings of disease in the breast (2). However, there are several malignancies that can metastasize to axilla as part of their symptoms or signs. Other malignant neoplasms including lung, thyroid, stomach, colon, rectum, pancreas and ovaries can present with axillary metastasis (2).

As for this patient, a thorough examination looking for breast pathology was done and did not reveal any finding. The routine imaging for breast cancer detection also had failed to detect any lesion. In order to help us to narrow down the possible organ, cytologic examination of the right axilla node was done and reported as metastasis that is most likely from the breast. Hence, we proceeded with MRI of the breast hoping to find any lesion. MRI has high sensitivity for detection of breast cancer ranging from $85-100 \%$ with specificity of 37 to $77 \%(2,4)$.
However, it was a negative result on MRI. Subsequently we proceeded with

PET CT for our patient and to our surprise, there was no uptake seen on the breast, only FDG uptake at the right axilla and right internal mammary lymph nodes. We decided to proceed with excision biopsy of the right axilla to help us to get to the diagnosis and further manage this patient. After the histopathology revealed a metastatic carcinoma suggestive of breast origin, we had a long discussion with the patient regarding the next surgical plan. We proceeded with mastectomy and axillary clearance and it showed a small focus of carcinoma $2 \times 1 \mathrm{~mm}$ in size with positive axillary lymph nodes.

Our MRI had failed to detect this small lesion and it is not a surprise to us as other cases reported by Karima Oualla et al also failed to detect a $12 \mathrm{~mm}$ lesion in the breast (2). Ritu Yadav et al investigated the role of mammoglobin expression as a diagnostic marker for breast cancer and found that $69 \%$ was expressed from 200 cases of breast cancer (5). However, in our case we did not send for mammoglobin test, as it was unavailable in our centre. Treatment for occult breast carcinoma varies based on the literatures. Traditionally, occult breast cancer treated with mastectomy and axillary node dissection but with the advent of breast MRI and improvement in radiation techniques, the management of this rare entity is changing and the practice patterns have steadily transformed over the last $2-3$ decades with a push towards breast conservation therapy, $\mathrm{BCT}(6,8)$. In some cases, the breast was preserved and only the axillary lymph nodes were removed. Karima Oualla et al reported 3 cases where they performed axillary lymph node dissection with preservation of the breast (2). These cases were negative on imaging, but axillary lymph node biopsy was proven metastatic carcinoma from breast origin. Post operatively all patients underwent whole breast irradiation and chemotherapy and at follow up of 8 months, no signs of loco regional recurrence in all patients.

Oluwadamilola et al reported 7 cases with occult breast carcinoma and 4 received modified radical mastectomy, 1 lumpectomy with axillary node dissection and 1 axillary node dissection only (3). In 5 patients with breast surgery, neither of them had intramammary tumour on histopathology. At 3 years, only one of them had contralateral breast recurrence and treated and at last follow up, all 7 patients are still alive without evidence of the disease (3). In other study conducted by Barton S.R et al in 2011, all 48 patients with occult breast carcinoma did not undergo mastectomy but majority ( 35 out 48 , $73 \%$ ) received ipsilateral breast radiotherapy (IBR) (7). The local recurrence free survival (LRFS) at 5 years was better in IBR than those who did not received IBR ( $84 \%$ vs. $34 \%$ in 5 years). The recurrence free survival also improved in IBR group than those who did not (64\% vs. $34 \%$ in 5 years), although the overall survival was not statistically significance (7). Most studies have shown that local therapy to ipsilateral breast either mastectomy or BCT plays a crucial role in treatment of primary breast cancer (8). In a retrospective study by Guiyun et al, they found no statistically significant difference in overall survival between patients underwent axillary node dissection, breast conserving surgery with axillary node dissection and mastectomy with axillary node dissection. However, they found better survival in those patients with N1 disease with no breast lesion compared to those in N2 and N3 category with no breast lesion (9). Hence, nodal status is an independent predictor of poor outcome in occult breast cancer patient (9).

While most studies or case reports highlighted the important use of radiotherapy, Yang et al reported 5 cases using neoadjuvant chemotherapy. Four out five patients were followed by mastectomy with axillary node dissection and radiotherapy gave a good outcome. Only one of them had recurrence after 2 years and treated with chemotherapy and trastuzumab and is well with no recurrence. One out five who received neoadjuvant chemotherapy did not undergo local treatment to the breast and axilla and on follow up did not show any signs of local recurrence or distant metastasis (10). As for our patient, we performed a mastectomy with axillary node dissection after a lengthy discussion with the patient. To our surprise, there was a small focus of infiltrating ductal carcinoma in our mastectomy specimen. Upon completion of her chemotherapy and radiotherapy, she is well with no loco regional recurrence detected and now undergoing treatment with trastuzumab.

\section{CONCLUSION}

Occult breast carcinoma is a challenging diagnosis for surgeon to treat. Breast conservation versus mastectomy should be discussed in detail with the patient. Ipsilateral breast radiation is an important adjuvant treatment especially those cases that breast conservation is planned for the patient. A multidisciplinary discussion among surgeon, radiologist, pathologist and oncologist is an important step in management such cases.

\section{Conflict of interest}

No conflict of interest was declared by the authors. 
6. Ahmaed I, Dharmarajan K, Tiersten A, Bleiweiss I, Schmidt H, Green S et al. A unique presentation of occult primary breast cancer with review of the literature. Case reports in oncological medicine,2015:1-5

1. Halsted WS. The results of radical operations for the cure of carcinoma of the breast. AnnSurg. 1907; 46: 1-19

2. Oualla K, Elm'rabey F, Airifi S, Mellas N, Melhouf MA, Bouhafa T et al. Occult primary breast cancer presenting as axillary nodal metastasis: report of 3 cases. Journal of Clinical Gynae and Obsteric. Oct 2012; 1 : 85-8

3. Fayanju OM, Jeffe DB, Margenthaler JA. Journal Surg Res. Dec 2013; 185: 1-8

4. Zhu YH, Luo MY, Jia Z, Guo JF Diagnoses and therapy of occult breast cancer: A systemic review. Journal of Mol Biomarker and Diagnosis. 2016;2: 1-8

5. Yadav R, Chauhan $P$, Sen R, Vashist M. Mammaglobin: As a diagnostic marker for breast cancer. Int journal of recent scientific research. 2015; 6: 7703-7706

7. Barton SR, Smith IE, Kirby AM, Ashley S, Walsh G, Parton M. The role of ipsilateral breast radiotherapy in management of occult primary breast cancer presenting as axillary lymphadenopathy. European Journal of Cancer. 2011;47: 2099-106

8. Walker GV, Smith GL, Perkins GH, Oh JL, Woodward W, Yu TK et al. Population-based analysis of occult primary breast cancer with axillary lymph node metastasis. Cancer, 2010;116: 4000-6

9. Sohn G, Son BH, Lee SJ, Kang EY, Jung SH, Cho SH et al. Treatment and survival of patients with occult breast cancer with axillary lymph node metastasis: A nationwide retrospective study. Journal of Surgical Oncology, 2014;110:270-4

10. Yang H, Li L, Zhang M, Zhang S, Xu S, Ma X. Application of neoadjuvant chemotherapy in occult breast cancer. Medicine, 2017; 96: 40-9 